\title{
Fifty Shades of Rokkan? Reconceiving Local Party System Nationalisation in Belgium
}

\author{
Kristof Steyvers" \\ An Heyerick \\ UDK $\quad 329.05(493)$ \\ 342.728(493) \\ Original scientific report / izvorni znanstveni rad \\ Received / primljeno: $\quad 9.10 .2017$. \\ Accepted / prihvaćeno: 22.12.2017.
}

This paper scrutinises local party system nationalisation, arguing for a more fine-grained approach beyond the default local-national dichotomy in order to acknowledge the shaded palette colouring the place-bound partisan canvas. Based on a typology of vertical decisional autonomy, the morphology of the local party system is firstly described as comprising national, pseudo-national, pseudo-local, and independent local lists. Secondly, this underpins a refined index applied to describe local party system nationalisation in the case of Belgium. Including the two most recent rounds of local elections, the paper accounts for variation in the index. Regression analysis shows that overall political ecology matters more than social morphology. More specifically, the number of inhabitants, metropolitan status, the relative vote share of national lists in antecedent

\footnotetext{
* Professor Kristof Steyvers, Centre for Local Politics, Department of Political Science, Ghent University, Belgium (profesor Centra za lokalne politike, Odsjek za političke znanosti, Sveučilište u Ghentu, Belgija, e-mail: Kristof.Steyvers@UGhent.be)

** An Heyerick, PhD, Veneco, Belgium (Veneco, Belgija, e-mail: an@veneco.be)
} 
local elections, and a relatively nationalised prior council composition significantly increase the odds of a nationalised local party system, whilst district magnitude has a significantly decreasing effect.

Keywords: party systems, nationalisation, local politics, national candidate lists, non-national candidate lists

\section{Introduction}

This paper aims to contribute to the study of local party system nationalisation. One strand in the literature conceives this as the uniform end state of the politicisation process at the local level. The Norwegian comparativist Rokkan (1966) was among the forebearers of this thesis, associating it with advancing modernisation. However, the enduring local presence and success of a range of non-national phenomena serves as an empirical counterfactual to this teleology. In this vein, contemporary scholars highlight that most such party systems mix local with national forces, changing their perspectives to understand the manifold shades that colour the local partisan canvas.

This paper builds on the latter view, arguing for a more fine-grained approach to replace the default local-national dichotomy. It assumes the local flag covers a diverse load of area-specific phenomena. Concentrating on a newly developed measure, the general objective of the paper is threefold. Based on a typology of vertical autonomy, the morphology of the local party system is firstly described as comprising national, pseudo-national, pseudo-local, and independent local lists. Secondly, this underpins a refined index applied to describe local party system nationalisation in the case of Belgium. Thirdly, the paper will study the explanatory power of specific social and political factors regarding variation in this index, including the two most recent rounds of local elections. This last objective emphasizes that persistent differences in nationalisation between municipalities need to be accounted for.

Belgium is a suitable case for this endeavour. Local elections are held every six years along a semi-open proportional list system, traditionally associated with a fragmented multiparty system consisting of local and national actors (Wauters et al., 2012). In the postwar era, a particularity developed insofar that genuinely national political parties ceased to exist. Stemming from the rise of regionalist parties, the traditional unitary pillar parties split into autonomous Flemish- and French-speaking factions, 
and newly-emerging counterparts were established accordingly. The party system is thus entirely segmented along regional lines. Literally, nationalisation should therefore be understood as regionalisation. Moreover, as a result of the ongoing federalisation process, local government has mainly come within the organic orbit of its respective regional counterpart, institutionally reinforcing the preceding partisan dynamic (Wayenberg et al., 2011). Therefore (supported by data availability), in the empirical section we will focus on the Flemish region in the north of Belgium (see also below for a more elaborate argumentation of the case selection).

The main aim of this paper is thus to develop, apply, and assess a more refined measure of local party system nationalisation. Before the core empirical section, the paper commences by situating the object of inquiry within the study of party systems focused on nationalisation and located at the municipal level, by engaging critically with existing conceptualisations.

\section{Local Party System Nationalisation: Towards a Reconceptualisation}

\subsection{Party System Nationalisation: Conceptions, Measures, and Findings}

In the multilevel approach to party systems, nationalisation has emerged as a key concept. Broadly, it pertains to the territorial homogeneity in the composition of the electoral offer and the distribution of electoral success over time and across space. Rooted in the work of Caramani (2004), this conception conceals an ongoing debate on the polysemic and multidimensional nature of nationalisation (Schakel, 2013; Lago \& Montero, 2014). Originally describing the degree to which a party's vote in territorial units varies over time, the dynamic conception of nationalisation revealed the extent to which voters react alike to statewide stimuli (Stokes, 1967). Its distributional counterpart focuses on the degree to which there is an equal division of party votes across territorial units (Morgenstern \& Swindle, 2005; Kasuya \& Moenius, 2008). Finally, a party-linkage variant probes into the extent to which candidates over a territory are linked together under a common party label (Chhibber \& Kollman, 2004). Geographical differences in party system constellations can thus be approached from a longitudinal (alternatively termed as process or dynamic) as well as a cross-sectional (outcome or static) angle. 
Different conceptions are accompanied by debates on alternative measures to determine the uniformity of swings across territories over different elections, the shares of constituencies in which specific parties compete (presence) and/or the votes the parties attract (performance) across these units. In a recent overview Bochsler (2010) discussed no less than 15 indices of static nationalisation alone, clustered in four families of measures: frequencies (share of contested districts), variances (variation of results in districts), distributions (Gini-coefficients of results in districts), and inflations (multilevel differences in the size of party systems) to introduce a new, more standardised indicator of his own (for other topical discussions, see Morgenstern, Polga-Hecimovich \& Siavelis, 2014; Lago \& Montero, 2014).

Increasingly refined yardsticks have yielded mixed results regarding the extent to which party system nationalisation could be empirically established within and between countries and/or over time. In his comparative-historical analysis Caramani (2004) discerned a general trend towards the territorial homogenisation of electoral behaviour. Since the mid-nineteenth century, party supply and support have become less place-bound. Consequently, peripheral electorates have been integrated into national political life and territorially segmented party systems have turned into national electoral constellations. Others (mostly from a country-specific and/or cross-sectional perspective) have been more sceptical, either rejecting nationalisation or emphasizing contingent variation therein (Jones \& Mainwaring, 2003; Morgenstern \& Swindle, 2005; Alemán \& Kellam, 2008).

Moreover, these conceptions, measures, and findings often pertain to different units of analysis and levels of aggregation. Some focus on the fate of the various parties, assessing their presence and/or success in all pertinent constituencies, with the aim of estimating the degree of nationwide homogeneity therein. Others take a more systemic perspective, probing into partisan configurations in given constituencies and surmising the extent to which these are nationalised (Morgenstern, Polga-Hecimovich \& Siavelis, 2014). This article belongs to the latter group in describing and explaining the nationalisation of local party systems and appraising this constituency-level feature for municipal elections.

\subsection{Bringing the Local Back in? Shifting the Nationalisation Vista}

We argue there is a clear contribution in this contention for and from that level. Much of the research mentioned in the previous section suffers from 
a 'methodological nationalism bias [...] to choose the state-wide level as the natural unit of analysis' (Schakel, 2013, p. 214) in actually addressing the territorial homogeneity of national party systems. Herein, the subnational (often termed as 'local') refers to the constituency level in national elections. To obtain a more integrated view, pleas developed for a multilevel outlook genuinely focusing on non-national elections and the extent to which their subsequent party system (dynamics) are nationalised (Mustillo \& Mustillo, 2012). This includes the municipal tier taking local party systems as an alternative frame of reference. To assess the degree to which local party systems resemble national ones, only relatively scarce evidence is available: '...what has so far remained almost entirely outside a research interest is an analysis of interconnectedness between local party systems and their (supra)system level formed by a national party system...' (Maškarinec, 2015, p. 629). However, there are exceptions and this article aims to build on the pertinent evidence to contribute to an improved estimation of local party system nationalisation.

Therein, the emergence over time of a nationalised supply and/or success is often conceived as indicative of a process of party politicisation. This is a central element in the work of Rokkan (1966, p. 244) associated with societal modernisation, implying ' $[. .$.$] the breakdown of the traditional systems$ of local rule through the entry of nationally organized parties into municipal elections'. Although an almost teleological takeover of local politics by national political parties is suggested, in many contexts traditional non-partisan elements continue to hold local ground. Apart from the remaining differences in the territorial anchorage of national political parties, this is due to the enduring presence and success of various types of non-national candidate lists in local polities (Aars \& Ringkjùb, 2005; Copus et al., 2012).

The cross-sectional approach then refers to the extent to which the national party political presence (the degree to which all statewide parties compete) and performance (the level of territorial homogeneity of their electoral results) at a given local election are geographically alike (Thorlakson, 2006). In line with most longitudinal findings, the sustained and contingent divergence in local party system nationalisation is often emphasized. Based on a discrete measure of assessing multilevel partisan resemblance, Kjèr \& Elklit (2010b) confirmed the positive effect of municipal size on nationalisation in the Danish context, whereas comparable evidence for Austria (Ensser-Jedenastik \& Hanssen, 2013) highlighted the additional explanatory value of the degree of party organisation.

Similar tendencies may be observed in Belgium. In the long run, national parties have effectively superseded merely place-bound phenomena in 
local elections. Generally, however, a straightforward and increasing nationalisation cannot be discerned. The presence, success, and shifts of and between parties are not homogenous for the whole country. Local results largely follow similar evolutions to those of national elections, but dissimilarities continue to characterise the geographical division of party systems (Wille \& Deschouwer, 2007). Similarly, supply-side evidence shows the local party field is infused with national candidate lists. Nevertheless, non-national counterparts have maintained their presence stemming from mixed or predominantly national local party systems (Steyvers et al., 2008).

So far, the discussion has concerned the systemic level, commonly focused on in the literature. Particularly in the case of local party systems, several authors have emphasized the importance of comparing nationalisation in different municipalities (with the possibility of distinguishing determinants of variance therein) instead of assessing the overall degree of approximation of local electoral patterns vis-ã-vis a national counterpart (Kjèr \& Elklit, 2010b; Maškarinec, 2015). Whilst acknowledging this, we argue, however, that a number of qualifications are needed on the parts that comprise it re-conceptualising some of the traditional approaches. This is also where the added value of our contribution lies.

An aggregated analysis showing trends for all municipalities traditionally uses a label to make the basic distinction between national lists (recognised local chapters of national parties) and their local counterparts (all other non-national local candidate lists). Most typologies of local party system nationalisation in Belgium start from such a nominal stance. In their pre-electoral formation, lists can have a protected name which can become national by means of a specific procedure (after the approval of the associated headquarters). It is thus a deliberate choice to address the voter locally with a national label. Alternatively, the use of a place-bound name expresses some willingness to localise the list label (Steyvers et al., 2008). Name-branding thus remains a relevant criterion to discern placebound phenomena from those which overarch local units (Reiser, 2008). Still, it remains incomprehensive in that it disregards polymorphous linkages between local and national party levels.

For one thing, the nominal approach implicitly assumes local chapters can be considered the dependent offspring of their national mother party. A recent strand in the literature alternatively adopts the analogy of franchise systems to describe the multifaceted relationship between centre and periphery in parties consisting of various autonomous territorial 
strata under a national label. Local chapters have considerable discretion in determining their own strategies and initiatives in centrally defined but mutually agreed frameworks. As a result, some parties are still characterised by hierarchy, while others show stratarchical or federative features (Bolleyer, 2012).

For another, complementing the diverse flag of 'national' lists, we also argue that their 'local' counterparts cover a diverse load. This heterogeneity has often been neglected in previous research. Hence, there is a lack of pertinent and applicable classification schemes giving nuance to the dichotomy and allowing us to differentiate between subtypes. This juxtaposition does not, for instance, account for the occurrence of border cases alternatively termed as pseudo-local lists or concealed party lists in the few existing exceptions to the treatment of non-national local candidate lists as a residual category (Reiser, 2008).

These arguments underscore the need to bring the local back in and disaggregate the shades of nationalisation at the municipal level. In the following section, we will develop a new measure of local party system nationalisation based on the vertical decisional autonomy of all place-bound candidate lists. This measure is applied and assessed in (one region of) Belgium. We argue this context is well-suited, primarily because of its consensual mode of local democracy. This is particularly expressed in the previously mentioned semi-open proportional list system associated with multiple representation of political parties in the municipal council. As indicated, in this system the adoption of a national or non-national name or label is a deliberate choice of local political actors seeking success (relatively easily achieved through the electoral formula). Second, the context is well-suited because of its tradition of communalism in inter-governmental relations. Belgian municipalities stem from the Southern and/or Napoleonic model, where relatively limited functions and discretion are complemented by rather direct access to the centre (through the accumulation of mandates and/or localised career paths) and an overall localised and political ethos of the system (long expressed through place-bound patronage and clientelism as opposed to functionalist agency). Whereas the regionalisation of local government and the associated reforms have had a substantial impact on different dimensions of the local political system, it is often argued the general features of this Belgian model are still upheld (Wayenberg et al., 2011). Overall, (municipal) politics is thus more local than central. Third, the combination of these institutional features provides the blueprint for the (dis)aggregated tendencies in local party system nationalisation discussed above, based on the existing literature. 
The suggested variety of local party system nationalisation over time and across space thus also makes this case empirically viable for the application and assessment of a more refined measure.

\subsection{Reconsidering the Shades: Vertical Decisional Autonomy Matters}

A more fine-grained taxonomy of local party system nationalisation should probe into the actual degree of independence of place-bound electoral lists from supra-local parties. This degree is closely aligned with decisional autonomy, identified by Randall \& Svæsand (2002) as a component of party institutionalisation. Adapting their definition to this research, it can be stated as the freedom from external influence on the policies and strategies of local candidate lists. Whereas such influence may emerge horizontally from other parties in the local system, for the purpose of this research we are interested in vertical decisional autonomy denoting the freedom from national party influence on local candidate list policies and strategies.

Empirical determination of the autonomy of (many) lists requires detailed insight into how policies and strategies are shaped, which is time-consuming and difficult to achieve. Therefore, in the operationalisation of vertical autonomy we consider freedom from explicit and/or implicit linkage to a national party as a proxy for independence. Consequently, four prototypical categories can be discerned (Heyerick \& Steyvers, 2013): 1) national party lists, which have a direct and nominal link with a national party; 2) extended national party lists, which complement the national party label with a local reference, creating some distance from the former level; 3) supported local lists, which are indirectly connected to a national party, making no reference to this in their label but maintaining linkage to it in practice; and 4) independent local lists, which have no links with a national party. Given the contemporary dynamics of the Belgian (local) party system, these four subtypes all have counterparts with a curtailed degree of horizontal autonomy in pre-electoral alliances termed cartels. As we focus on vertical autonomy in this paper, these will be considered together with the accompanying subtypes outlined above, resulting in the eventual distinction between 1) national, 2) pseudo-national, 3) pseudo-local, and 4) independent local lists.

This fourfold typology has subsequently been applied to all lists which participated in the last two rounds of local elections (in 2006 and 2012) in the 308 municipalities in Flanders $(\mathrm{N}=1,458$ and 1,647). First, we 
looked for the presence of explicit links to a national party inferred from the list name adopted in each local election. ${ }^{1}$ This allowed us to separate national lists $(\mathrm{N}=1,053$ and 1,193) from all others with a (partial) local denomination ( $N=405$ and 454). Second, and to distinguish between the two, implicit links to national parties were scrutinised. Obviously, these were harder to establish and required a more thorough analysis of the targeted lists. This was achieved by: 1) analysing all associated media reports published in national newspapers during the six months preceding the local elections concerned, ${ }^{2} 2$ ) checking or complementing this information through the website of the respective non-national list and/or national party, and 3) contacting the front-runner of the list concerned by telephone in case of doubt. ${ }^{3}$ Table 1 displays the results of this classification.

Table 1: Distribution of local candidate list subtypes in local elections according to vertical autonomy

\begin{tabular}{|l|c|c|c|c|}
\hline \multirow{2}{*}{ Subtype list } & \multicolumn{2}{|c|}{2006} & \multicolumn{2}{c|}{2012} \\
\cline { 2 - 5 } & $\%$ & $\mathrm{~N}$ & $\%$ & $\mathrm{~N}$ \\
\hline National & 72.2 & 1,053 & 72.4 & 1,193 \\
\hline Pseudo-national & 4.7 & 69 & 6.1 & 100 \\
\hline Pseudo-local & 8.6 & 125 & 8.8 & 145 \\
\hline Independent local & 14.5 & 211 & 12.7 & 209 \\
\hline Total & 100 & 1,458 & 100 & 1,647 \\
\hline
\end{tabular}

Source: authors

The table demonstrates the predominance of national lists on the local electoral scene. Just over $72 \%$ are nominally recognisable, place-bound

${ }^{1}$ Publicly available on the website of the Flemish Agency for Internal Affairs: http:// www.vlaanderenkiest.be

2 Publicly accessible online via the database GoPress: http://www.gopress.be. This contains articles from quality newspapers and tabloids. Most have regional pages including information on local elections. The database was mined using the name of a non-national local candidate list and/or the municipality as keywords.

${ }^{3}$ Implicit links to (a) national party(ies) were assumed if the list was presented in media reports as a) an initiative of one or more local party branch(es), b) containing one or more dominant group(s) of members from a national party, or c) the front runners of the list were presented as prominent supra-local officeholders from a national party. Other suggested individual national links were thus disregarded. Our conception is thus mainly concerned with collective linkage. 
chapters of national political parties. This share is constant in both rounds of elections. The remainder (just under 28\%) thus electioneers under a (partially) local denominator. Almost half of these have either partially explicit or implicit links to a national party. Pseudo-local lists are more prevalent than their pseudo-national counterparts. A small majority of non-national local candidate lists can be termed as genuinely independent. In the most recent local elections these proportions have remained largely constant. It may be noted that the share of independent local lists has decreased mainly to the benefit of their pseudo-national counterparts. Overall, more than $85 \%$ of all lists have links to national parties, constricting their scope of vertical autonomy to differing degrees. ${ }^{4}$

\subsection{Reconfiguring the Canvas: Indexing Local Party System Nationalisation}

For the remainder of this paper we will return to the systemic level. The typology of vertical decisional autonomy allows us to aggregate in more detailed fashion the assemblage of the local partisan canvas and the degree to which this resembles its supra-local counterpart in every municipality. Therefore, we have developed a discrete index of local party system nationalisation, taking the ratio between the subtypes set out above into consideration. For the exploratory purpose of this paper, the index will concentrate on the number of lists of each subtype (on their relative share in the party system). These numbers are weighted by a factor reflecting their actual linkage to national political parties: a) national lists: factor $=2$; b) pseudo-national lists: factor $=1$; c) pseudo-local lists: factor $=-1$ and c) independent local lists: factor $=-2$. This weighting inflates the pure types on the poles of nationalisation-localisation, to add the appropriate relief to the continuum.

These weighted numbers are then added up and the result is divided by the total number of lists in the local party system for standardisation. The index of local party system nationalisation can thus be represented by the following formula:

$$
\mathrm{I}_{\mathrm{LPSN}}=[(2 \mathrm{a}+\mathrm{b})-(\mathrm{c}+2 \mathrm{~d})] / \mathrm{n},
$$

${ }^{4}$ Previous research (Heyerick \& Steyvers, 2013) has probed into the political relevance of these subtypes, determining independent local lists to be most diversified. Many authorized face difficulties achieving representation. 
with $\mathrm{a}=$ the number of national lists, $\mathrm{b}=$ the number of pseudo-national lists, $\mathrm{c}=$ the number of pseudo-local lists, $\mathrm{d}=$ the number of independent local lists, and $\mathrm{n}=$ the total number of lists.

In line with the distinction between the electoral (lists participating in local elections) and the parliamentary (lists obtaining representatives in the local council) party system (Kjèr \& Elklit, 2010a) and to take greater account of the political relevance of the various subtypes, two variants of the index are calculated: a) the electoral index of local party system nationalisation $\left(\mathrm{EI}_{\mathrm{LPSN}}\right)$ and $\mathrm{b}$ ) the parliamentary index of local party system nationalisation $\left(\mathrm{PI}_{\mathrm{LPSN}}\right){ }^{5}$

The index thus expresses the weighted ratio between the number of (pseudo-)national and (pseudo-)local lists, allowing the incorporation of the relative importance of vertical decisional autonomy in the assertion of the local party system (in elections or in the council). It ranges from +2 in completely nationalised local party systems to -2 in their fully place-bound counterparts. This reflects recent developments in the general nationalisation literature arguing that '.. a perfectly nationalised party system is a party system with only national parties or, in other words, without sub-national parties' (Lago \& Montero, 2014, p. 201). Moreover, our measure clearly takes the systemic perspective called for in the specifically locally-oriented literature mentioned above (Maškarinec, 2015) by comparing partisan configurations between municipalities. In addition, its different variants analytically distinguish between the supply (authorisation) and demand (representation) side of the local party system nested in the families of frequency and variance in nationalisation measurement (Bochsler, 2010). Finally, the measure incorporates the party-linkage approach to nationalisation, as it emphasizes the importance of the extent to which candidates in a particular territory are linked together under a common party label (Chhibber \& Kollman, 2004). However, by including the distinction between national and non-national lists, the index acknowledges one of the key specificities of local elections (Kjèr \& Elklit, 2010a) whilst also adding an assessment of within-group variation in the latter type. This combination of features makes the index better suited to refined measurement.

Taking into account the relative share of each subtype, a standardised measure pertinent to local party system nationalisation has thus been established.

${ }^{5}$ For the latter index, only the number of lists of a subtype represented in the council has been taken into account, with the total number of lists adjusted accordingly. 
The figures below display key measures on the electoral and parliamentary indices for the local elections of 2006 and 2012.
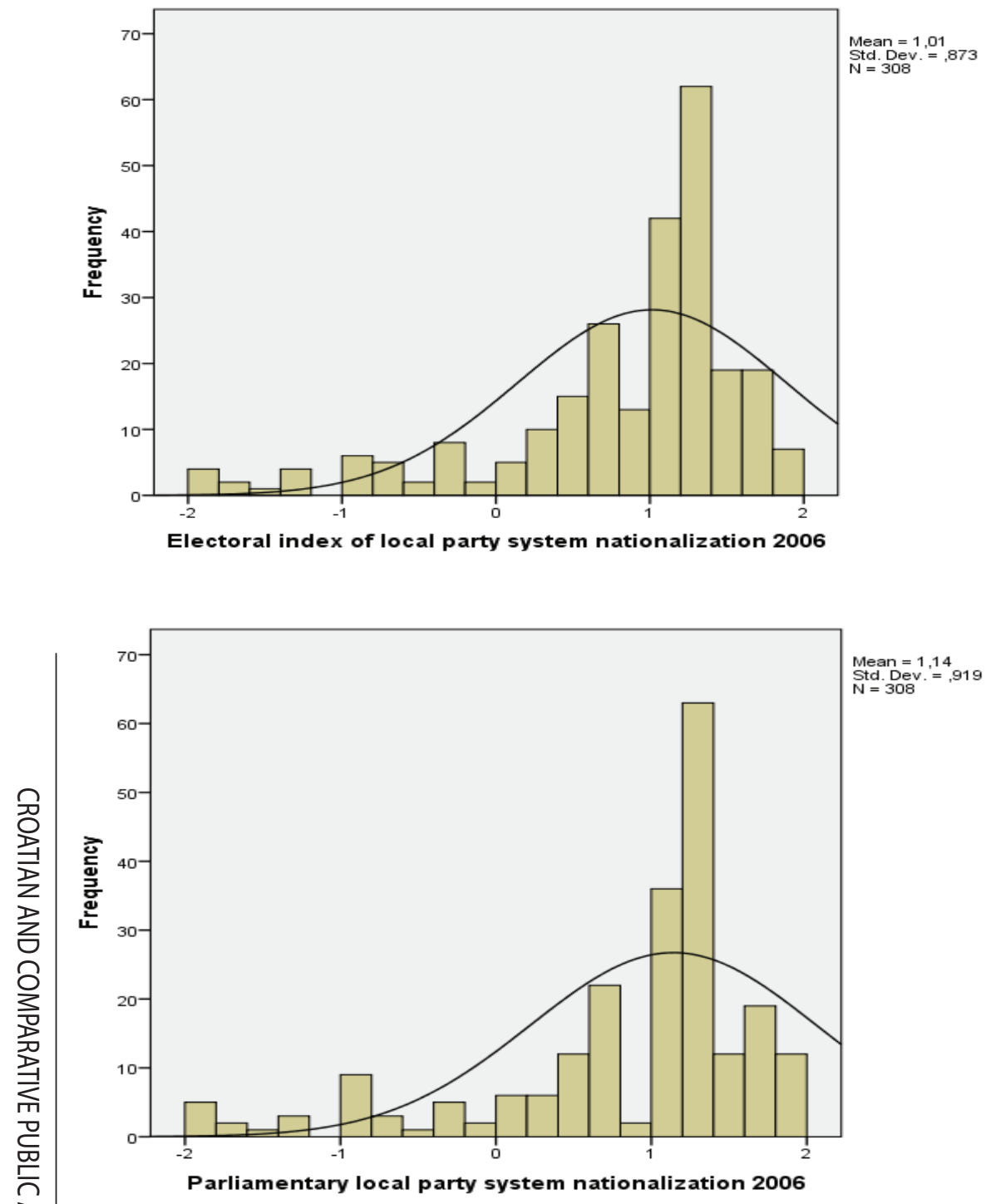

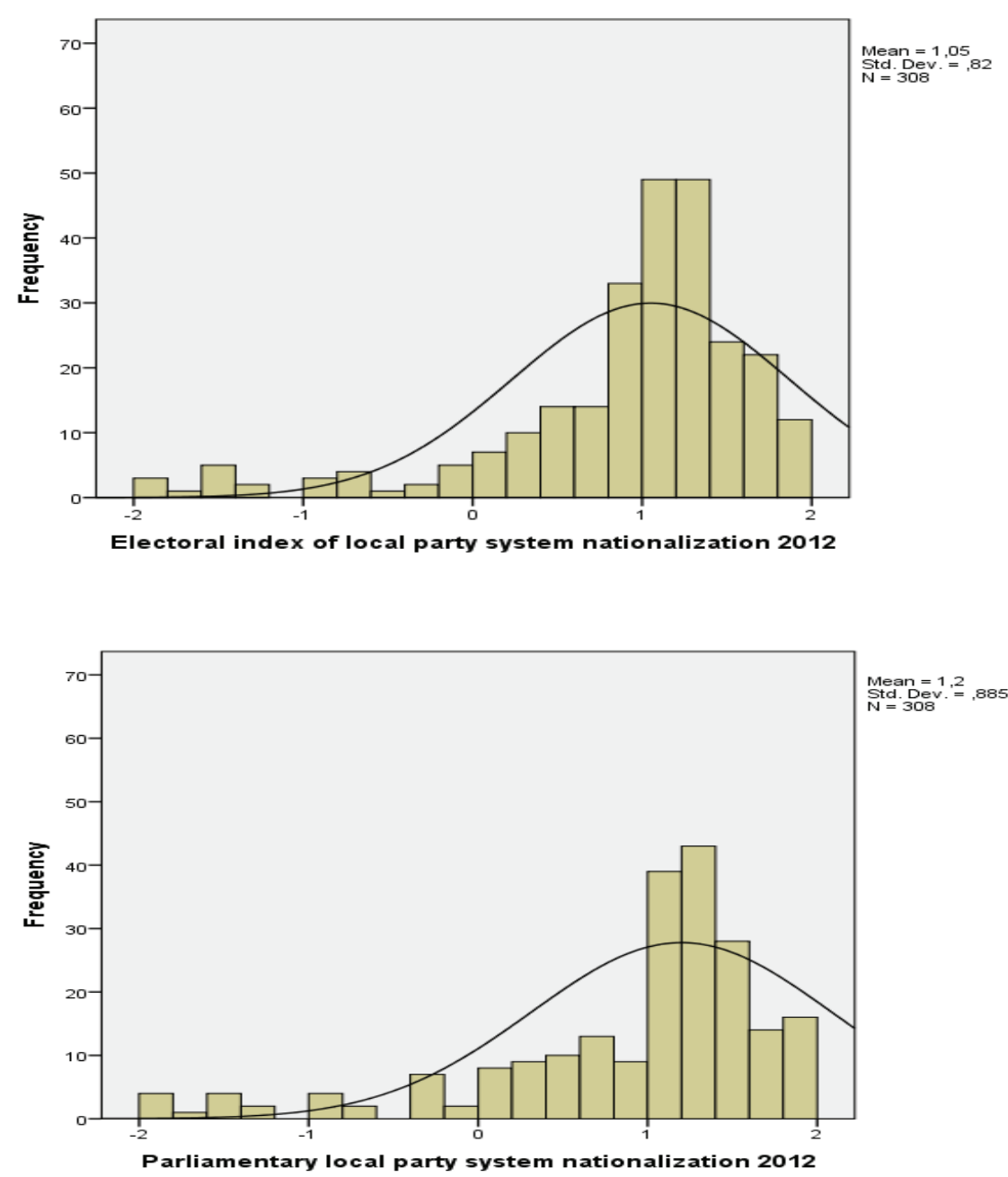

Source: authors

The figures point to an undercurrent of relative local party system nationalisation. The mean and the median vary from 1.0 to 1.2 (with standard deviation between 0.8 and 0.9 ) and from 1.2 to 1.3 respectively. The kurtosis indicates a peak towards the mean, whilst the skewness confirms a relative long tail to the left. The electoral indices are on average relatively lower than their parliamentary counterparts. In the eventual council composition, the nationalisation of the local party system is more prominent than in the preceding partisan supply. Comparing 2006 with 2012, the pattern remains highly similar with a slight increase of local party system nationalisation. 
Given this distribution, and for logistic regression purposes explained below, discrete index scores were categorised into four specific ranges of relative local party system nationalisation leading to the following subtypes: a) nationalised party systems $=1$ to $2, \mathrm{~b}$ ) pseudo-nationalised party systems $=1$ to 0 , c) pseudo-localised party systems $=0$ to -1 , and d) localised party systems $=-1$ to -2 . Here also, a distinction between the electoral and the parliamentary arena was made. Table 2 displays the relative share of these subtypes.

Table 2: Relative share of local party system types according to nationalisation

\begin{tabular}{|l|c|c|c|c|}
\hline \multicolumn{1}{|c|}{ Election } & \multicolumn{2}{c|}{2006} & \multicolumn{2}{c|}{2012} \\
\hline Arena & Electoral & $\begin{array}{c}\text { Parliamen- } \\
\text { tary }\end{array}$ & Electoral & $\begin{array}{c}\text { Parliamen- } \\
\text { tary }\end{array}$ \\
\hline Nationalised & 54.9 & 63.3 & 53.9 & 64.0 \\
\hline Pseudo-nationalised & 32.8 & 24.7 & 35.4 & 25.0 \\
\hline Pseudo-localised & 6.8 & 5.5 & 6.2 & 6.2 \\
\hline Localised & 5.5 & 6.5 & 4.5 & 4.8 \\
\hline
\end{tabular}

Source: authors; $\mathrm{N}=308$

The table indicates the majority of all municipalities have a nationalised electoral arena. This share increases to about two out of three for its parliamentary counterpart, suggesting that non-national candidate lists face greater hurdles in obtaining representation. Regarding pseudo-nationalised local party systems, the ratio between both arenas is reversed. Whereas about one third of all municipalities have an electoral offer that can be termed accordingly, this is the case for around one fourth of all associated councils. More localised party systems are rather uncommon. Taken together, (pseudo-)localised party systems characterised the electoral or parliamentary arena of around one out of every eight (2006) to nine (2012) municipalities. Localised party systems are generally least prevalent.

\section{Getting the Picture: Accounting for Variation in Local Party System Nationalisation}

In this section, we will account for variation in local party system nationalisation. First, we will introduce the explanandum (the nationalised 
subtype of the local party system). Second, the explanans will be outlined, along sets of variables respectively labelled as social morphology and political ecology. Their explanatory direction and strength will be tested by binary logistic regression.

\subsection{Explanandum: Nationalised Local Party System}

For the dependent variables, we refer to the subtypes of local party system nationalisation based on the re-categorised electoral and parliamentary index scores. Particularly, we will try to account for the nationalised subtype of these indices.

We argue that this is both theoretically as well as empirically meaningful. First, the associated index scores (1-2) reflect the undercurrent of relative nationalisation, still leaving substantial room for the potential relevance of non-national candidate lists with differing degrees of national linkage. Within this category both semi- as well as fully nationalised local party systems are included. Second, this theoretically relevant distinction also divides the population into empirically practicable shares vis-ã-vis the dependent reference category. For both reasons, it is preferred over alternatives based on measures of central tendency or the marginal frequency distribution of the discrete indices which in themselves are too skewed for linear regression.

Given the exploratory nature of this research, we will focus on the most recent local elections. This will also allow us to include some derivatives of the data gathered for their preceding counterparts to account for different aspects of path dependency in the local party system (cf. infra). The dependent variable in the analysis will thus be the position of a locality outside (0) or inside (1) the nationalised electoral and parliamentary local party system in the municipal elections of 2012. For reasons of clarity, the hypotheses below do not differentiate between expected effects for presence in elections and representation in councils.

\subsection{Explanans: Between Social Morphology and Political Ecology}

Two sets of independent variables will be incorporated, accounting for local party system nationalisation. Each contains various explanatory factors inspired by the sparse pertinent literature and made operational in a 
manner argued to be meaningful in the Belgian context. The factors will be formulated so as to expect significantly increased odds for a municipality to dispose of a nationalised local party system. The comparability of these effects and the overall parsimony of the models are enhanced by a dichotomisation of the original indicators.

Does social morphology matter? One string of independent variables refers to the wider social morphology of the municipality against which more specific political thrusts are moulded. Specifically, three dimensions will be covered.

First, differences in nationalisation have been associated with variation in municipal size: 'the local party system in more populous municipalities tends to resemble the party system at the national level more than is the case in smaller municipal units' (Kjèr \& Elklit, 2010a, p. 425). Size tends to work through intermediate variables such as political diversity, however. Larger municipalities have a heterogeneous social makeup, implying a complex cleavage structure and diversified partisan interests. These demand-side explanations are reinforced by an increased place-bound supply of national political parties associated with enhanced size. In larger municipalities, local councils are seen as an organisational base from which national parties can mobilise important resources (Kjèr \& Elklit, 2010b).

This relationship has often been corroborated in empirical research. In contrast, non-national local candidate lists have traditionally fared better in smaller municipalities, associated with more harmonious and factual modes of local decision-making (Steyvers et al., 2008; Kjèr \& Elklit, 2010b; Ennser-Jedenastik \& Hansen, 2013). However, in recent decades, alternatives to national parties have established themselves in larger cities as well, indicating the emergence of newer types of non-national lists allegedly embodying anti-system sentiments (Reiser, 2008).

Hence, two indicators of size have been included in our analysis, to grasp related but not interchangeable aspects relevant in Belgium. On the one hand, with the traditional criterion of the number of inhabitants we discern the relatively larger from the smaller municipalities. ${ }^{6}$ On the other hand, population density has been measured analogously. ${ }^{7}$ This should help to distinguish municipalities that are sizeable in terms of inhabitants,

\footnotetext{
${ }^{6}$ This distinction is based on the marginal frequency distribution of the number of inhabitants. The highest refers to the third of municipalities where this is above 18,643 ( $\mathrm{N}$ $=105$ or $34.1 \%)$.

7 This distinction is based on the marginal frequency distribution of population density. The highest refers to the third of municipalities where this is above 556 inhabitants per square kilometre $(\mathrm{N}=103$ or $33.4 \%)$.
} 
but cover a polycentric area consisting of numerous smaller settlements, from their more consolidated mono-centric counterparts. We expect that population (number and density) will increase the odds of a nationalised local party system. Hence, two hypotheses (with subdivisions into $a$ and $b$ for each dimension of the local party system type) will be tested:

H1: In municipalities with the highest number of inbabitants the odds of an electoral (a) or parliamentary (b) nationalised local party system are significantly bigher.

H2: In municipalities which are the most densely populated the odds of an electoral (a) or parliamentary (b) nationalised local party system are significantly bigher.

Second, we assert the effect of metropolitan status on local party system nationalisation. The emergence of metropolitan regions and the embedding of municipalities therein has been identified as one of the main trends of contemporary political geography (Sellers et al., 2013). In Belgium, the official conception outlines these regions as the overarching layer of an urban agglomeration and its (suburban) banlieue. For inclusion of specific localities, functional zones have been adjusted to municipal administrative divisions (Steyvers, 2009). ${ }^{8}$

Metropolitan status is often considered to be the topical variant of the traditional centre-periphery divide, invoking delineated sources of political behaviour. Recent comparative research has demonstrated that metropolitan ecologies shape whether citizens vote and according to which ideological orientations they do so. Most research has concerned the geometry of national cleavage structures in the metropolis, identifying typical strongholds of the right and left (Sellers et al., 2013). Less attention has been paid to the relative presence and success of national versus non-national candidate lists therein.

Explorative research for Belgium has discerned some tendencies. The closer to the metropolitan core, the more nationalised the overall political offer. Metropolitan location matters equally regarding voter demands. In central cities (centre-)left wing voting is more popular with an electoral

8 The urban agglomeration is the central city before the sprawl; i.e., the city centre, with its 19th century extensions and its 20th century outskirts. The banlieue is the outer zone of the metropolis; i.e., the spatial expression of suburbanisation from the urban agglomeration. Population density and spatial planning in terms of housing form the base for distinguishing the agglomeration from its banlieue. Commuting, population growth, and immigration serve as criteria for the inclusion of a municipality in the metropolitan region. 
landscape much more polarised in national terms and limited electoral leeway for non-national candidate lists. In the (outer) suburbs and outside the metropolitan area (centre-)right wing voting predominates. For local lists the pattern differs with relatively higher shares in the inner suburbs and outside the metropolis (Steyvers, 2009).

For the purposes of this research, a distinction is made based on the typology mentioned and the assignment of specific localities therein in order to separate municipalities inside (part of an urban agglomeration or its banlieue) from their counterparts outside a metropolitan region. ${ }^{9} \mathrm{We}$ expect the odds of a nationalised local party system to be higher in the former. Hence, one hypothesis will be tested:

H3: In municipalities that are part of a metropolitan region the odds of an electoral (a) or parliamentary (b) nationalised local party system are significantly bigher.

Third, the effect of socioeconomic morphology will be scrutinised. This arguably differs from the demographic configuration (i.e. size) and the spatial location (i.e. metropolitan status) of the municipality. In her comparative conclusions on local lists, Reiser (2008) already hints at the general importance of such factors; however, more specific empirical evidence linking socioeconomic features to local electoral tendencies is scarce. Existing explorations concern the relationship between specific socioeconomic characteristics of the municipality and the presence and success of one or more particular parties (e.g. Hooghe et al., 2010). We assume that these findings can be extended to the aggregated level, linking the socioeconomic status of a municipality with local party system nationalisation.

For this paper, we have derived this status from a typology often adopted by the regional government (Dessoy et al., 2007). This is based on a factor analysis of data on just over a hundred characteristics collected for each municipality, eventually clustered in six subgroups for sixteen clusters. We have ultimately aggregated the subgroups of municipalities with central functions (central), with a concentration of economic activity (industrial), or which are semi-urban or an agglomeration (urban) into one category, expected to be associated with higher odds of a nationalised local party system. ${ }^{10}$ Hence, one hypothesis will be tested:

\footnotetext{
${ }^{9}$ Metropolitan status refers to the position of a specific municipality inside a metropolitan region $(\mathrm{N}=109$ or $35,4 \%)$.

${ }^{10}$ For central, industrial, or urban municipalities $\mathrm{N}=120$ or $39 \%$.
} 
H4: In municipalities that are central, industrial, or urban the odds of an electoral (a) or parliamentary (b) nationalised local party system are significantly bigher.

Does political ecology matter? Another string of variables refers to the electoral features of the local political milieu pertaining to the more specific institutional and partisan ecology of the municipality.

Here, the literature is in even shorter supply. However, there are some relevant clues in the seminal work of both Reiser and Holtmann (2008) on the presence and performance of non-national candidate lists that may benefit from aggregative reframing in terms of local party system nationalisation by connecting two of their central slants and adding a third.

First, Reiser (2008) stresses the importance of the organisational capacity of parties. The penetration of national lists into the local electoral arena has a strong negative effect on the vote shares of non-national ones. In a substantial number of European countries national candidate lists are only present in a minority of municipalities, facing difficulties competing under their label and vying with the perception that politics at this lev$\mathrm{el}$ is factual and harmonious and thus hostile to partisan conflict. Here, non-national candidate lists are the only groups running. However, whenever they run, national lists are almost invariably able to occupy a large share of the vote. Non-national lists thus tend to fill the voids and '[...] benefit predominantly from the low [presence] or even total absence of political parties' (Reiser, 2008, p. 289).

From an aggregate perspective, this could imply that the more firmly national lists are entrenched in a locality, the higher the nationalisation of its party system. However, the risk arises of a rather circular interpretation. If the presence and performance of national and non-national lists correlate, which is then the consequence of the other? The above suggests the key decision lies with national lists: if they choose to run, they tend to appropriate the bulk of the vote and their non-national counterparts can only act as surrogates or by filling the remaining electoral gaps. Yet, this initial decision in turn seems to be influenced by a preceding assessment of their political viability in a given municipality. Consequently, in a mere cross-sectional analysis co-variation can hardly be distinguished from causality.

To overcome this, the time factor should be integrated. This relates to the second core empirical finding of the comparative research described above. Reiser (2008) emphasized the importance of path dependencies in political traditions conceived as enduring place-bound focal points of non-national candidate lists. Here also, an aggregated postulate could be 
derived, arguing that the stronger the tradition of national candidate lists in a given municipality, the higher the nationalisation of its local party system. An antecedent predominance of national candidate lists in a certain locality will constitute barriers to non-national alternatives. Ideally, such a history-sensitive approach includes longitudinal measurement over various electoral cycles. Because we only have at our disposal sufficiently fine-grained and comprehensive data for 2006, and additionally assuming that the political conditions at the end of the previous cycle will be most decisive for the dynamics at the beginning of the next cycle, we will use the data for the 2006 elections as our point of reference.

Combining national party entrenchment with political tradition, three indicators will be used to scrutinise the effect of the anterior degree of national party organisation on current local party system nationalisation. As the first indicator, the electoral local party system type in 2006 will be used, dichotomising nationalised from non-nationalised variants. This takes the antecedent ascendancy of national lists in the partisan offer into consideration. The second indicator probes into the relative success of national lists in the 2006 local elections, discerning municipalities where this was above average from those where this was not. ${ }^{11}$ This clarifies the voting preponderance of lists with explicit links to national politics. As the third indicator, the parliamentary local party system type in 2006 will be considered, making an analogous distinction between nationalised and non-nationalised variants. This highlights the subsequent representative primacy of national lists in the council. We expect that each of these antecedents will increase the odds for a currently nationalised party system type. Hence, three hypotheses will be tested:

H5: In municipalities where the anterior electoral local party system was nationalised, the odds of an electoral (a) or parliamentary (b) nationalised local party system are significantly bigher.

H6: In municipalities where the anterior vote for national parties was relatively bigher, the odds of an electoral (a) or parliamentary (b) nationalised local party system are significantly bigher.

H7: In municipalities where the anterior parliamentary local party system was nationalised, the odds of an electoral (a) or parliamentary (b) nationalised local party system are significantly bigher.

${ }^{11}$ For this variable, the mean $(76.3 \%)$ is preferred as a cut-off point because the marginal frequency distribution suggests a strong skewness to the right. For vote share for national lists in 2006 relatively high $\mathrm{N}=193$ or $62.6 \%$. 
A third empirical finding of the comparative research mentioned is the effect of within-country differences in the institutional framework of local elections. Here, the impact of substantial alterations and/or in-built differentiation of the electoral system are frequently cited. In Belgium, virtually no pertinent reforms have been enacted which substantially affect the semi-open proportional list system (Wauters et al., 2012). One aspect of institutional difference exists, however, in the variation in the number of seats up for election, often termed as the district magnitude. In their account of Denmark, Kjèr and Elklit (2010b) have included this as a control variable, finding the sustenance of an autonomous size-effect with district magnitude having a significantly positive effect on the parliamentary variant of local party system nationalisation. Moreover, in explaining local party system fragmentation in Belgium, Geys (2006) found significant interaction effects between district magnitude and social heterogeneity, suggesting an electoral arena more open to accommodating the full array of national political forces. Building on these findings, we assume that where district magnitude is highest, the odds of a nationalised local party system will increase. ${ }^{12}$ Hence, one hypothesis will be tested:

H8: In municipalities where the district magnitude is bighest, the odds of an electoral (a) or parliamentary (b) nationalised local party system are significantly bigher.

\subsection{Results: Logistic Regression}

The relationship between the independent variables and their dependent counterparts is studied by means of binary logistic regression. This will help us to assess the direction, the strength $(\operatorname{Exp}(B))$, and the significance (Sign) of the odds that a municipality has a nationalised electoral or parliamentary local party system, given its morphological and ecological features in the independent covariates. The analysis consists of two models, the first of which only includes the morphological characteristics of the municipality and the second which adds ecological variables. Some independent variables correlate significantly. However, further diagnostics based on the variance inflation factor do not raise problems of multicollinearity. We will discuss each model in turn within both moulds

\footnotetext{
12 This distinction is based on the marginal frequency distribution of the number of seats. The highest refers to the third of municipalities where this is above 25 ( $N=105$ or $34.1 \%)$.
} 
of the nationalised local party system type. Significant covariates are displayed in bold. The overall explanatory power of the models is expressed by Nagelkerke $\mathrm{R}^{3}$. Table 3 displays the results.

Table 3: Results of the binary logistics regression analysis

\begin{tabular}{|c|c|c|c|c|c|c|c|c|}
\hline \multirow{4}{*}{$\begin{array}{l}\text { Independent variables } \\
\text { Social morphology }\end{array}$} & \multicolumn{8}{|c|}{$\begin{array}{l}\text { Dependent variable. Local party system type } \\
\text { [nationalised; 2012] }\end{array}$} \\
\hline & \multicolumn{4}{|c|}{ Electoral } & \multicolumn{4}{|c|}{ Parliamentary } \\
\hline & \multicolumn{2}{|c|}{ Model 1a } & \multicolumn{2}{|c|}{ Model 2a } & \multicolumn{2}{|c|}{ Model $1 b$} & \multicolumn{2}{|c|}{ Model $2 b$} \\
\hline & $\operatorname{Exp}(B)$ & Sign & $\operatorname{Exp}(B)$ & Sign & $\operatorname{Exp}(B)$ & Sign & $\operatorname{Exp}(B)$ & Sign \\
\hline Number of inhabitants [h] & 1.53 & .12 & 2.67 & .09 & 3.61 & .00 & 7.68 & .00 \\
\hline Population density [h] & 0.85 & .56 & 0.64 & .17 & .96 & .90 & 0.67 & .27 \\
\hline Metropolitan status & 1.06 & .84 & 1.15 & .65 & 1.88 & .04 & 2.37 & .02 \\
\hline Central/industrial/urban & 0.83 & .45 & 0.78 & .39 & 1.31 & .34 & 1.24 & .51 \\
\hline \multicolumn{9}{|l|}{ Political ecology } \\
\hline Electoral nationalised 2006 & & & 1.10 & .82 & & & 0.91 & .86 \\
\hline Vote share national lists 2006 [rh] & & & 4.29 & .00 & & & 3.10 & .00 \\
\hline Parliamentary nationalised 2006 & & & 2.65 & .05 & & & 5.24 & .00 \\
\hline District magnitude 2012 [h] & & & 0.24 & .02 & & & 0.23 & .05 \\
\hline Nagelkerke $\mathrm{R}^{3}$ & .01 & .60 & .30 & .00 & .14 & .00 & .41 & .00 \\
\hline
\end{tabular}

Source: authors; $\mathrm{N}=308$

In model 1a joint morphological variables do not significantly increase the odds of a municipality having an electorally nationalised local party system. The overall explanatory power of the model is very low and none of the separate variables has a significant effect. Social morphology does not seem to matter for the relative presence of national candidate lists over their non-national counterparts. Therefore, and with regard to model 1a, H1-4a cannot be confirmed.

As model $1 \mathrm{~b}$ shows, joint morphological variables significantly increase the odds of a municipality having a parliamentary nationalised local party system. The overall explanatory power of the model remains relatively low but is significant. This is particularly due to the positive effect of the number of inhabitants and the metropolitan status of a municipality. In the relatively largest municipalities the odds are about four times higher, whereas in those that belong to a metropolitan region the odds are about two times higher. For population density and central, industrial, or urban 
status no significant effects appear. Aspects of social morphology thus do matter for the relative representation of national candidate lists over their non-national counterparts. Therefore, and with regard to model $1 \mathrm{~b}, \mathrm{H} 1 \mathrm{~b}$ and $\mathrm{H} 3 \mathrm{~b}$ can be confirmed whereas $\mathrm{H} 2 \mathrm{~b}$ and $\mathrm{H} 4 \mathrm{~b}$ cannot.

In model $2 \mathrm{a}$ the overall explanatory power increases to $30 \%$. This is entirely due to adding political ecology variables. Again, morphological variables jointly do not significantly increase the odds of a municipality having an electorally nationalised local party system. The same holds for each of the morphological variables considered separately. Among political ecology variables, the vote share for national lists in the preceding local elections is most determinative. Where this share was above average, the odds increased by a factor of more than four. To a lesser extent significance also holds for the effect of the antecedent parliamentary local party system. Where this was nationalised in 2006, the odds are just under three times higher for the electoral party system in 2012 to be nationalised. Path dependencies thus do matter. The electoral preponderance of national lists in the preceding local elections and their subsequent representative primacy seem to elevate barriers for the proliferation of non-national alternatives. But not all path dependencies matter: the nationalisation of the anterior electoral party system did not significantly affect that of its successor. Whereas previously demonstrated vote-stacking capacity matters, prior pre-electoral ascendency does not. Remarkably, the effect of district magnitude defies our expectations: in municipalities where the highest number of seats are up for election, the odds of the local partisan offer being nationalised decrease significantly. With regard to model 2a, H6a and H7a can be confirmed whereas H1-5a and H8a cannot.

Finally, in model $2 \mathrm{~b}$ the $\mathrm{R}^{3}$ amounts to just over $40 \%$. Now both types of variables produce significant effects, almost combining the predictors of model $1 \mathrm{~b}$ and $2 \mathrm{a}$. Here also, the number of inhabitants and metropolitan status matter. Where this number is relatively highest or municipalities are within a metropolitan region, the odds of the parliamentary local party system being nationalised increase with a factor of just under eight and just over two respectively. Municipal context factors thus co-determine the representative primacy of national lists. But not all of them do: the effects of population density or the central, industrial, or urban status of a municipality are not significant. Similar effects to those for electoral nationalisation can be found for political ecology factors. Here the best predictor of actual parliamentary nationalisation is its antecedent in 2006 (the odds are more than five times higher). This is followed by the vote share for national lists in the preceding local elections. Where this was 
above average, the odds are just over three times higher. The effect of district magnitude is highly comparable to that for the electoral local party system. Where the highest number of seats are contested, the odds of a national predominance in the council are significantly lower. Therefore, and with regard to model $2 \mathrm{~b}, \mathrm{H} 1 \mathrm{~b}, \mathrm{H} 3 \mathrm{~b}, \mathrm{H} 6 \mathrm{~b}$, and H7b can be confirmed whereas $\mathrm{H} 2 \mathrm{~b}, \mathrm{H} 4 \mathrm{~b}, \mathrm{H} 5 \mathrm{~b}$, and H8b cannot.

\section{Conclusion and Discussion}

This paper has scrutinised local party system nationalisation, emphasizing a more fine-grained approach beyond the hitherto predominant national versus non-national dichotomy, in order to acknowledge the shaded palette colouring the place-bound partisan canvas. Three main points stand out, furthering existing research.

First, a more refined assessment of the vertical autonomy of the parts comprising the system has been developed, invoking the subtypes of national, pseudo-national, pseudo-local, and independent local lists. Applying this to all lists which took part in the last two rounds of local elections has demonstrated the Flemish municipal scene is dominated by lists having at least implicit links to a national party. This refines previous conclusions accentuating the imprint of such parties with an array of non-national forces maintaining relevance. It additionally underlines that local name-branding still matters. A substantial number of lists with a non-national denomination uphold at least implicit national linkage, suggesting the contingent electoral viability of a de-franchised mould (Steyvers et al., 2008).

Second, this typology has been inserted to assess the nationalisation of the place-bound partisan assemblage. We have developed discrete indices of local party system nationalisation expressing the ratio between the subtypes outlined above in both the electoral and the parliamentary arena. Scores pointed at the undercurrent of relative local party system nationalisation. Based on a re-categorisation of the discrete values, nationalised, pseudo-nationalised, pseudo-localised, and localised local party system subtypes have been discerned, with a majority of all municipalities situated in the first. Nationalisation is more prominent in the council than in the electoral offer. This fine-tunes the prevalence of mixed or predominantly national party systems of previous categorical research in Belgium (Steyvers et al., 2008). The alleged end-state of exclusive nationalisation 
has thus not been reached in a large majority of municipalities, both due to the persistence of independent local lists as well as of those (partly) concealing their linkage to national parties.

Third, the paper has tried to explain variation in local party system nationalisation by considering the conjoined effect of place-bound social morphology and political ecology variables hitherto considered less systematically (Reiser, 2008; Kjèr \& Elklit, 2010a and b; Ennser-Jedenastik \& Hansen, 2013). With the nationalised subtypes as dependent references, binary logistic regressions show that overall political ecology matters more (often) than social morphology. Taken together the covariates are also more predictive for the parliamentary variant of local party system nationalisation than for its electoral counterpart, further accentuating the distinction between the presence and performance of various types of lists.

Also, further particular effects appear. First, morphological factors do not significantly increase the odds of the electoral local party system being nationalised. This applies both when considered in isolation as well as in conjunction with their ecological counterparts. In other words, context does not matter for the relative nationalisation of the partisan supply. Second, specific morphological factors (number of inhabitants, metropolitan status) do matter for the parliamentary local party system to be nationalised. Context thus matters for the relative nationalisation of partisan success. Third, the same specific ecological factors matter for both electoral and parliamentary party system nationalisation. Here, the particular relevance of path dependency as the preceding degree of national party organisation comes to the fore. The anteriorly demonstrated vote-stacking capacity of national political parties stands out particularly, confirming the assumptions of both Reiser and Holtmann (2008). Unexpectedly, the significant effect of district magnitude on both aspects of nationalisation was negative and needs further research.

Ultimately, a substantial amount of variance remains unexplained. Herein lie the limits of a quantitative approach focusing on the effect of exogenous social and political conditions on local party system nationalisation. Notwithstanding the merits of measuring nationalisation through the aggregated vertical autonomy of all place-bound lists, circumstances can only partially account for systemic variation. Arrangements of decisional autonomy are equally driven by endogenous factors within specific lists and are often affected by temporal contingencies of place, calling for in-depth qualitative assessments (Heyerick \& Steyvers, 2013). To fully understand local party system nationalisation, the interaction between 
exogenous conditions and endogenous decisions should thus further be tackled in a triangulated manner.

Finally, as with the level central in this analysis, our insights are to a certain extent place-bound. It may be assumed that our measure for Belgium will travel well to similar contexts with proportional list systems and multiparty configurations (e.g. the Nordic countries) and/or with an ethos of communalism underlying the local political system (e.g. the Southern European countries). Developing and assessing equivalents for non-proportional and/or two-partisan systems (e.g. the Anglo-Saxon world), countries where the ethos of local government is more functional (e.g. the Rhinelandic countries) and/or (national) parties have a less developed rooting at the local level (e.g. many of the Central and Eastern European countries) might prove a bit more difficult. This paper is thus a first step in brushing the place-bound shades on the Rokkan canvas and an open invitation for more comparative portraits.

\section{References}

Aars, J., \& Ringkjùb, H.-E. (2005). Party politicization reversed? Non-partisan alternatives in Norwegian local politics. Scandinavian Political Studies, 28(2), 161-182.

Alemán, E., \& Kellam, M. (2008). The nationalisation of electoral change in the Americas. Electoral Studies, 27(2), 193-212.

Bochsler, D. (2010). Measuring party nationalisation: A new Gini-based indicator that corrects for the number of units. Electoral Studies, 29, 155-168.

Bolleyer, N. (2012). New party organization in Western Europe: Of party hierarchies, stratarchies and federations. Party Politics, 18(3), 315-336.

Caramani, D. (2004). The nationalisation of politics: The formation of national electorates and party systems in Western Europe. Cambridge, United Kingdom: Cambridge University Press.

Chhibber, P., \& Kollman, K. (2004). The formation of national party systems. Princeton, NJ: Princeton University Press.

Copus, C., Wingfield, M., Steyvers, K., \& Reynaert, H. (2012). A place to party? Parties and nonpartisanship in local government. In S. Clarke, P. John \& K. Mossberger (Eds.), The Oxford handbook of urban politics (pp. 210-230). Oxford, United Kingdom: Oxford University Press.

Dessoy, A., Erauw, A., \& Rombouts, W. (2007). Lokale financiën: Sociaaleconomische typologie van de gemeenten [Local finances. A Socio-Economic Typology of Municipalities]. Brussels, Belgium: Belfius. 
Ennser-Jedenastik, L., \& Hansen, M. (2013). The contingent nature of local party system nationalisation: The case of Austria 1985-2009. Local Government Studies, 39(6), 777-791.

Geys, B. (2006). District magnitude, social heterogeneity and local party system fragmentation. Party Politics, 12(2), 281-297.

Heyerick, A., \& Steyvers, K. (2013, July). How local are local lists? A quantitative and qualitative analysis of local lists in Flanders. Paper presented at the ECPR General Conference, Bordeaux, France.

Hooghe, M., Heyndels, B., Jottier, D., Birsan, T., \& Botterman, S. (2007). Explaining the Green vote: Belgian local elections 1994-2006. Environmental Politics, 19(6), 930-950.

Holtmann, E. (2008). Local lists in Europe. In M. Reiser \& E. Holtmann (Eds.), Farewell to the party model? Independent local lists in East and West European countries (pp. 11-19). Berlin, Germany: Springer VS.

Jones, M., \& Mainwaring, S. (2003). The nationalisation of parties and party systems: An empirical measure and application to the Americas. Party Politics, 9(2), 139-166.

Kasuya, Y., \& Moenius, J. (2008). The nationalisation of party systems: Conceptual issues and alternative district-focused measures. Electoral Studies, 27, 126-135.

Kjèr, U., \& Elklit, J. (2010a). Party politicization of local councils: Cultural or institutional explanations for trends in Denmark (1966-2005). European Journal of Political Research, 49(3), 337-358.

Kjèr, U., \& Elklit, J. (2010b). Local party system nationalisation: Does municipal size matter? Local Government Studies, 36(3), 425-444.

Lago, I., \& Montero, J. (2014). Defining and measuring party system nationalisation. European Political Science Review, 6(2), 191-211.

Maškarinec, P. (2015). Nationalisation of the Czech local party system: Case study of the 2010 local elections in municipalities with extended powers. Sociológia, 47(6), 625-656.

Morgenstern, S., Polga-Hecimovich, J., \& Siavelis, P. (2014). Seven imperatives for improving the measurement of party nationalisation with evidence from Chile. Electoral Studies, 33, 186-199.

Morgenstern, S., \& Swindle, S. (2005). Are politics local? An analysis of voting patterns in 23 democracies. Comparative Political Studies, 38(2), 143-170.

Mustillo, T., \& Mustillo, S. (2012). Party nationalisation in a multilevel context: Where is the variance? Electoral Studies, 31(2), 422-433.

Randall, V., \& Svæsand, L. (2002). Party institutionalization in new democracies. Party Politics, 8(1), 5-29.

Reiser, M. (2008). Conclusion: Independent local lists in Eastern and Western European countries. In M. Reiser \& E. Holtmann (Eds.), Farewell to the party model? Independent local lists in East and West European countries (pp. 277294). Berlin, Germany: Springer VS. 
Rokkan, S. (1966). Electoral mobilization, party competition and national integration. In J. Weiner (Ed.), Political parties and political development (pp. 241-265). Princeton, NJ: Princeton University Press.

Sellers, J., Kübler, D., Walks, A., Rochat, P., \& Walter-Rogg, M. (2013). Conclusion: Metropolitan sources of political behaviour. In J. Sellers, D. Kübler, M. Walter-Rogg \& A. Walks (Eds.), The political ecology of the metropolis: Metropolitan sources of electoral behaviour in eleven countries (pp. 419-478). Colchester, United Kingdom: ECPR Press.

Steyvers, K. (2009, January). Metropolitan inequality and governance in Belgium: A cuckoo in the nest of political localism? Paper presented at the meeting of the International Metropolitan Observatory, Los Angeles, USA.

Steyvers, K., Reynaert, H., De Ceuninck, K., \& Valcke, T. (2008). All politics is local, partisan or national? Local lists in Belgium. In E. Holtmann \& M. Reiser (Eds.), Farewell to the party model? Independent local lists in East and West European Countries (pp. 169-194). Wiesbaden, Germany: VS Verlag.

Stokes, D. (1967). Parties and the nationalisation of electoral forces. In W. Chambers \& W. Brunham (Eds.), American party systems: Stages of political development (pp. 188-202). Oxford, United Kingdom: Oxford University Press.

Thorlakson, L. (2006). Party systems in multi-level contexts. In D. Hough \& C. Jeffery (Eds.), Devolution and electoral politics (pp. 37-52). Manchester, United Kingdom: Manchester University Press.

Wauters, B., Verlet, D., \& Ackaert, J. (2012). Giving more weight to preferential votes: Welcome or superfluous reform? The case of the local elections in Flanders (Belgium). Local Government Studies, 38(1), 91-111.

Wayenberg, E., De Rynck, F., Steyvers, K., \& Pilet, J.-B. (2011). Belgium: A tale of regional divergence? In J. Loughlin, F. Hendriks \& A. Lidström (Eds.), The Oxford handbook of local and regional democracy in Europe (pp. 71-95). Oxford, United Kingdom: Oxford University Press.

Wille, F., \& Deschouwer, K. (2007). Het beschermde dorp: Nationale tendensen bij gemeenteraadsverkiezingen [The protected village: national tendencies in municipal elections]. Res Publica, 49(1), 67-88. 


\section{FIFTY SHADES OF ROKKAN? RECONCEIVING LOCAL PARTY SYSTEM NATIONALISATION IN BELGIUM}

\section{Summary}

This paper scrutinises local party system nationalisation beyond the national versus non-national dichotomy in the context of Belgium. Three main points stand out. First, a more close-knit assessment of the vertical autonomy of the parts comprising the system invokes the subtypes of national, pseudo-national, pseudo-local, and independent local lists. Applying this to all those who took part in the last two rounds of local elections demonstrates the Belgian municipal scene is predominated by lists having at least implicit links with a national party (even when their label is non-national). Second, this typology has been insert$e d$ to assess the nationalisation of the place-bound partisan assemblage. We have developed discrete indices of local party system nationalisation expressing the ratio between the subtypes outlined above in the electoral and the parliamentary arena. Scores pointed to relative local party system nationalisation, without reaching its alleged end-state. Nationalisation is also more prominent in the council than in the electoral offer. Third, the paper tried to explain variation in local party system nationalisation by considering the conjoined effect of place-bound social morphology and political ecology variables. Binary logistic regression shows that overall political ecology matters more (often) than social morphology (being more predictive for the parliamentary than for the electoral variant of the index). Also, further particular effects appear. First, morphological factors do not significantly increase the odds of the electoral local party system being nationalised. Second, specific morphological factors do matter for the parliamentary local party system to be nationalised. Third, the same specific ecological factors matter in the case of both electoral and parliamentary party system nationalisation. Here, the particular relevance of path dependency as the preceding degree of national party organisation comes to the fore. Ultimately, a substantial amount of variance remains unexplained. Herein lie the limits of a quantitative approach focusing on the effect of exogenous conditions on local party system nationalisation. To fully understand this, the interaction with endogenous within-party decisions should be tackled. Future research also needs to assess if, how far, and under which conditions our insights travel comparatively. Keywords: party systems, nationalisation, local politics, national candidate lists, non-national candidate lists 


\title{
ROKKANOVIH PEDESET NIJANSI? REKONCEPCIJA NACIONALIZACIJE LOKALNOG POLITIČKOG SUSTAVA U BELGIJSKOM KONTEKSTU
}

\begin{abstract}
Sažetak
U radu se istražuje nacionalizacija lokalne politike u belgijskom kontekstu. Problematici se pristupa detaljnije od tradicionalne podjele stranaka na nacionalne i nenacionalne, te se izvode tri glavna zaključka. Prvo na temelju analize vertikalne autonomije stranaka možemo zaključiti da postoje četiri podtipa liste: državne, pseudodržavne, pseudolokalne i nezavisne lokalne liste. Podjela sudionika posljednjib dvaju krugova belgijskib lokalnib izbora na navedena četiri podtipa pokazuje da prevladavaju, što se belgijskih općina tiče, liste koje su makar neizravno povezane s državnom strankom (čak i kada nemaju državni predznak). Nadalje, ova se tipologija koristi kako bi se procijenila nacionalizacija lokacijski ograničenog skupa stranaka. Razvijeni su indeksi nacionalizacije lokalne politike koji pokazuju omjer izmedu navedenih podtipova u izbornoj i u parlamentarnoj areni. Rezultati upućuju na to da je riječ o relativnoj, a ne o potpunoj nacionalizaciji lokalnog političkog sustava. Nacionalizacija je izraženija u slučaju lokalnib vijeća nego lokalnib izbora. Konačno, u radu se nastoji objasniti varijacija u nacionalizaciji lokalnog političkog sustava razmatranjem zajedničkog učinka varijabli lokacijski ograničene društvene morfologije $i$ političke ekologije. Binarna logistička regresija pokazuje da je politička ekologija (češće) važnija od društvene morfologije (predvidljivija je u slučaju parlamentarnog indeksa nego u slučaju izbornoga). Javljaju se $i$ drugi učinci. Morfološki faktori ne utječu znatno na vjerojatnost da će doći do nacionalizacije izbornoga lokalnog političkog sustava, no pojedini morfološki faktori ipak utječu na nacionalizaciju parlamentarnoga lokalnog političkog sustava. Nadalje, isti ekološki faktori utječu na nacionalizaciju kako izbornog tako $i$ parlamentarnog lokalnog političkog sustava. Tu je izražena važnost dotadašnjeg razvojnog puta $i$ prethodnib odabira (path dependance) koji utječu na nacionalizaciju lokalne politike. Ipak, varijacija u velikoj mjeri ostaje naobjašnjena, što je povezano sograničenjima kvantitativnog pristupa usmjerenoga na učinak vanjskib utjecaja na nacionalizaciju lokalne politike. Kako bi se postiglo cjelovito razumijevanje, valja proučiti interakciju s unutarnjim stranačkim odlukama. Buduća se istraživanja također trebaju usmjeriti na komparativnu primjenu rezultata - u kojoj je mjeri i u kojim uvjetima moguća.

Ključne riječi: stranački sustavi, nacionalizacija, lokalna politika, državne liste kandidata, ne-državne liste kandidata
\end{abstract}

